\title{
ABOUT A ROLE OF BIOLOGICAL DIVERSITY IN THE PHYTOSANITARY OPTIMIZATION OF AGRARIAN LANDSCAPES
}

\author{
E.Yu. Toropova' ${ }^{1}$ I.G. Vorob'eva ${ }^{2}$, V.A. Chulkina $^{1}$, E.Yu. Marmuleva ${ }^{1}$ \\ ${ }^{1}$ Novosibirsk State Agrarian University, 160, ul. Dobrolyubova, Novosibirsk, 630039 Russia \\ e-mail:helento@ngs.ru,victor@lapasrv.sscc.ru \\ ${ }^{2}$ Siberian University of Consumer Cooperation, 26, prosp. Karla Marksa, Novosibirsk, 630087 Russia \\ e-mail: helento@ngs.ru
}

Received November 21, 2012

Sum mary

\begin{abstract}
The ecological compatibility of plant cultivation technologies involves the ecological management not only in the agrocenosis, but also in adjacent to them nature stations constituent the agrolandscapes. Phytosanitarian situation in modern agroecosystems of Western Siberia requires a stabilization on two the most numerous and harmful ecological groups of damaging organisms - soil-inhabiting or root-tuberous, and surface-inhabiting or leaf-stem. In the forest-steppe zone of Novosibirsk oblast' and Altai the authors estimated a phytosanitarian state of the plants and a soil in the conditions of factory farms. It was shown, that the mechanisms of realization of biological variety creation considerably differ for ecological groups of soil-born and air-born harmful organisms. For soil-born species it is effectively to create a biological variety in time by alternation of crops in rotations, and for air-born - mosaic distribution of different plant species in space.
\end{abstract}

Keywords: agrarian landscape, crop rotation, phytosanitary predecessor, crops' mixture, biological variety, plant protection.

Ecologization of plant growing technology is a priority direction of modern agriculture. This approach provides the ecologically oriented control of both agrocenoses and surrounding natural habitats that form agricultural landscapes (1). Management of agricultural landscapes comes out of a real need in protection of cultivated crops against plant pathogens, because natural habitats closely interact with agrocenoses through migrations of the insect fauna, plant pathogens, and weeds. The degree of this association is different and it must be considered in development of systems for phytosanitary monitoring and forecasting the state of agricultural ecosystems, as well as technologies of crop cultivation (2).

Phytosanitary condition of modern agroecosystems of Western Siberia requires stabilization in respect of two most numerous and harmful ecological groups of pests that damage underground (roots and tubers) and aboveground organs of plants (leaves and stems) pathogens (3). Specific strategies of their life cycles (K-strategy in soil and r-strategy aboveground) underlie differential approaches of pest control and the content of programs and methods used for increasing biodiversity of agricultural biocenoses.

The purpose of this study was investigating the efficiency of methods for increasing biological diversity of agricultural landscapes in respect to the control of soil and ground pest population.

Technique. Studies were carried out in 1990-2012 in the forest-steppe zone of Novosibirsk province and Altai territory in the territory of agricultural enterprises, along with model experiments conducted following the conventional methods. The effect of legume/cereal mixture on phytosanitary condition and yield of Sudan grass was evaluated on a test plot of $84 \mathrm{~m}^{2}$ area with 4 -fold repeatability. Seeds of Sudan grass (cv Novosibirskaya 84), peas (cv Novosibirets), vetch (cv Priobskaya 14), and beans (cv Sibirskie) were sown in different proportions. Mowing of the green mass was performed twice: the $1^{\text {st }}-$ in early flowering, $2^{\text {nd }}-$ after the regrowth of green mass at the end of growing season. Observations of entomofauna of forage crops were carried out in crop rotation fields of the Siberia Research and Development Institute of Fodder (Krasnoobsk settlement of Novosibirsk province) .

Phytosanitary condition of plants was determined by standard methods (4), soil - by flotation method (5), the insect fauna was accounted according to the recommended methods (6).

The obtained data were statistically processed in SNEDEKOR software package (7).

Results. In specialized farms of Siberia, crop rotation commonly have significant share of cereals (55.6-84.6\%) and low biodiversity. There was observed a strong correlation $(r=0.862 \pm 0.017)$ between the maximum population density of common root rot pathogen Bipolaris sorokiniana Sacc. (Shoem.) in soil and the frequency of growing spring wheat with cereals-predecessors. In Western Siberia, sequential cultivation of cereals resulted in significant accumulation in soil of resting structures of plant pathogens, and in more than $80 \%$ of this area population density of these pathogens exceeded the economic threshold of harmfulness (ETH). In this region, the highest identified population of plant pathogens in soil after cereal crops amounted to $40 \mathrm{ETH}$, which leads to epiphytotic root rot and up to $50 \%$ loss of spring wheat and barley $(8,9)$.

\section{Phytosanitary condition of soil in agricultural enterprises with different systems of crop} rotation (forest-steppe zone of Novosibirsk province and Altai territory, 1990-2006)

\begin{tabular}{|c|c|c|c|}
\hline \multirow{2}{*}{ Characteristic } & \multicolumn{3}{|c|}{ Agricultural Enterprise } \\
\hline & "Zarya" & "Listvyansky" & "Medvedevsky" \\
\hline Total area infected with & root rot & $\%$ & \\
\hline Above the threshold of harmfulness $(\mathrm{TH})$ & 28.0 & 70.5 & 100 \\
\hline Below TH or pathogen-free & 72.0 & 29.5 & 0 \\
\hline Acreage of particular crops in & rotation & s y s t e m, \% & \\
\hline 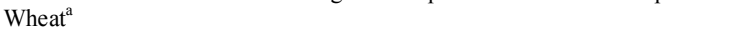 & 22.2 & 10.5 & 53.8 \\
\hline Oats $^{\mathrm{a}}$ & 14.8 & 31.6 & 15.4 \\
\hline Winter rye $^{\mathrm{a}}$ & 3.7 & 0 & 0 \\
\hline Vetch-oats ${ }^{\text {b }}$ & 14.8 & 0 & 0 \\
\hline Perennial herbs (legumes/cereals) ${ }^{\mathrm{b}}$ & 7.4 & 5.3 & 0 \\
\hline Millet & 3,7 & 0 & 0 \\
\hline Buckwheat & 0 & 0 & 7.7 \\
\hline Peas & 0 & 5.3 & 0 \\
\hline Maize & 22.2 & 21.0 & 0 \\
\hline Fallow & 11.2 & 21.0 & 15.4 \\
\hline System of crop rotation (total number of crops) & $8+$ fallow & $6+$ fallow & $4+$ fallow \\
\hline Sources of reproduction of Bipolaris sorokiniana, $\%$ & 40.7 & 42.3 & 69.2 \\
\hline Highly effective phytosanitary predecessors, $\%$ & 22.2 & 5.3 & 0 \\
\hline
\end{tabular}


Population of harmful soil organisms can be controlled by increasing the biodiversity of crop rotation lands that limits lifetime of plant pathogens. Thus, the analysis of crop rotations in several farms of Novosibirsk province (Table) showed that phytosanitary condition of soils in respect to a common root rot pathogen B. sorokiniana Sacc. (Shoem.) worsened with increasing (from 40 to $70 \%$ ) the proportion of cereal crops that stimulate reproduction of the pathogen (wheat, barley, winter rye) and a simultaneous reduce (from 22.2 to $0 \%$ ) in proportion of effective phytosanitary predecessors, such as legume/cereal mixtures, soybeans, rapeseed, maize, and peas. The highest biodiversity was found in crop rotations including about $70 \%$ healthy areas, which was $50 \%$ higher than those in crop rotations where $100 \%$ arable land was infected with root rot agents with a population density above the threshold of harmfulness

Increasing biodiversity of crop rotation by introduction of phytosanitary predecessors significantly improves phytosanitary condition of soil in respect to soil pathogens as well as other harmful organisms. In this study, the reduce in root rot infestation of underground organs of plants was accompanied by the decline in damage caused by stem pests up to $74.2 \%$ and weeds - by $22.7 \%$.

To control the population of leaf-stem pathogens it is necessary to increase biodiversity within a field agrocenosis (such as poly-cropping) in order to limit spatial propagation of pests. Thus, it was shown that poly-cropping cultivation of Sudan grass with legumes (peas, beans, and vetch) limited the development of leaf-stem infection - particularly, Pseudomonas holci Kendrick and Helminthosporium turcicum Pass. in years of observation. This approach enables the following mechanisms: reducing the amount of susceptible tissues and pathogen population within a plantation; increasing the distance between susceptible plants; mechanical barrier of immune species preventing the transfer of pathogen.

The increase of biodiversity of plant species reliably limited the extent of plant diseases during the observation period (20012003). The most stable phytosanitary effect was obtained in the variant of joint cultivation of Sudan grass and beans at almost equal proportions of crops: the degree of leaf-stem infection was $22.0 \%$ lower on the average over the years compared with that in monoculture of Sudan grass. Similar positive results were observed in the variant of Sudan grass sown joint with peas at a ratio of 7:4. Thus, biological effect of poly-cropping in the control of leaf-stem diseases of Sudan grass averaged $7.6-9.4 \%$ for the $1^{\text {st }}$ mowing and $11.6-22.0 \%$ for the $2^{\text {nd }}$ one. In general, phytosanitary optimization of crops was achieved in $63.0 \%$ cases at the $1^{\text {st }}$ mowing and in $81.5 \%$ cases at the $2^{\text {nd }}$ mowing, which indicates the effectiveness of biodiversity against various leaf-stem pathogens.

Today, implementation of the principle of biodiversity is considered as the most promising way to control population of terrestrial phytophages that represent over $80 \%$ pathogenic entomofauna in Western Siberia; this can be done by increasing the number of species and population of both flora and fauna involved in a three-level trophic system and stimulation of natural mechanisms of pest population control.

According to own data $(2,10)$ and scientific publications $(11,12)$, biodiversity of crop rotations can be improved by inclusion of fragments of natural ecosystems with a relatively stable and more diverse composition of flora and fauna: balks, fallow lands, forest shelter belts, small parklands, as well as inconvenient non-arable lands that serve as environmental micro- and macroreserves .

Population and activity of beneficial entomofauna can be effectively increased by target development of sustainable selfcontrolled adaptive agroecosystems that include nectariferous species planted within a field (along the roads, balks, forest belts, parklands on the area of 10-15\%), forest belts and parklands formed by trees and shrubs that attract entomophages and stimulate their activity, such as birds and other beneficial organisms, as well as mosaic distribution of nectariferous plantations in agroecosystems of crop rotation (considering the radius of action of many entomophages up to $500 \mathrm{~m}$ during the growing season). Agrocenoses are available to entomophages when there is performed a partial mowing of vegetation in roadsides and nearby habitats (especially in fields of perennial grasses), sowing fields of reduced width, or in croplands alternated with special narrow balks.

In Western Siberia, ecologization of agrocenoses is naturally supported by existing sparse-growing forests and parklands, a part of which in Novosibirsk and Omsk regions was designated to natural reserves for flora and fauna (13). In each farm with entomophilous crops it is mandatory to allocate several fields (1-2 hectares) for reservations of natural pollinators and entomophages; these fields must be free from any treatment with pesticides, plowing, grazing, mechanized mowing, and landfill.

Systematic observations (2006-2012) of entomofauna of forage crops revealed taxonomic diversity of entomophages necessary for stabilization of phytophages specific to these crops. In the studied crop rotations, many forage crops were grown in small fields (1-5 ha) with mosaic location of species related to three botanical families: Fabaceae (field beans, soybeans, chickpeas, clover, vetch, peas), Poaceae (brome grass, Sudan grass, maize, millet, oats, wheat, rye), and Brassicaceae (rapeseed, oilseed radish). The abundance of flowering plants in continuous plantations attracted entomophages of many taxonomic groups supported by minimum pesticide load (just occasional herbicide treatment of soybean). According to the observations, in each crop there were annually accounted entomophages from 6-8 groups represented by 30-40 species of predators and parasites. Such taxonomic diversity provided effective ratio phytophage/entomophage for the most of three-level trophic system allowing to avoid treatment crops with insecticides.

Entomophages (Syrphidae, Coccinellidae, Chrysopidae, Aphidiidae, Braconidae, Carabidae, etc.) notably reduced populations of pests - cabbage whiteflies, aphids, plant-eating bugs, fall webworm, etc. For example, populations of major pathogens of field beans - weevils (Sitona lineatus L. and S. crinitus Hbst.) were effectively controlled by entomophagous beetles from six genera (Bembidion, Pterostichus, Calatchus, Carabus, Broscus, Calasoma) with the ratio entomophage/phytophage equal to 1:2.3 $1: 3.4$.

A significant role in attraction of beneficial insects and insect-eating birds is played by forest belts and hedgerows composed of flowering entomophilous trees and shrubs (14). The latter can significantly increase biodiversity of the insect fauna and provide a suitable place for nesting, which may enrich the middle tier of such plantations. Trees and bushes planted in these belts must be adapted to Siberian conditions and approved as suitable phytosanitation species. There should be preferred intensely flowering nectariferous forms, especially those with a long flowering period that will not complicate but stabilize phytosanitary condition of agricultural landscapes in respect to ground phytopathogens and phytophages. It is desirable to create blooming belts of ornamental trees and shrubs, such as sequentially flowering representatives of the genera Padus (Virginia bird cherry), Pentaphylloides (shrubby 
cinquefoil), Rosa (rugosa rose, burnet rose), Crataegus (Chinese hawthorn and other species), etc. However, tree plantations that promote propagation and survival of harmful pests of agricultural crops must be excluded from phytosanitary belts or isolated from agrocenoses (15). Phytosanitary belts and hedgerows are especially important for phytosanitary optimization of plantations of fruit and berry crops (16).

Thus, increasing the biodiversity of agricultural landscapes in fact is the simulation of natural homeostasis preventing overpopulation of particular species. Its accurate implementation based on principles and approaches of phytosanitary optimization of agrocenoses allows effective management of phytosanitary condition of agricultural landscapes in terms of all biological (phytopathogens, herbivores, weeds) and major environmental (root-tuber and leaf-stem pests) groups of harmful organisms. In pest control of soil pathogens, the maximum effect provides biological diversity of crops-edificators alternated in time, while for terrestrial destructive biota it's more efficient the mosaic spatial distribution of different plant species. Practical realization of biological diversity in agroecocenoses allows self-control of phytosanitary objects up to $30-50 \%$ pests' populations.

\section{REFERENCES}

1. Toropova E.Yu., Stetsov G.Ya., Chulkina V.A. Epifitotiologiya /Pod red. A.A. Zhuchenko, V.A. Chulkinoi [Epiphytoty. A.A. Zhuchenko, V.A. Chulkina (eds.)]. Novosibirsk, 2011.

2. Chulkina V.A., Toropova E.Yu., Stetsov G.Ya. Ekologicheskie osnovy integrirovannoi zashchity rastenii /Pod redaktsiei M.S. Sokolova, V.A. Chulkinoi [Ecological Bases of Integrated Crop Protection. M.S. Sokolov, V.A. Chulkina (eds.)]. Moscow, 2007.

3. Toropova E.Yu., Stetsov G.Ya., CHulkina V.A. Epifitotiologicheskie osnovy sistem zashchity rastenii /Pod redaktsiei V.A. Chulkinoi [Basic Epiphytotic Approaches to the Plant Protection Systems. V.A. Chulkina (ed.)]. Novosibirsk, 2002.

4. Tanskii V.I., Levitin M.M., Ishkova T.I., Kondratenko V.I. Metodicheskie rekomendatsii po zashchite rastenii [Guidelines for Plant Protection]. St. Petersburg, 1998: $5-55$.

5. Sostavlenie i primenenie fitopatologicheskikh pochvennykh kartogramm (FPK) po zaselennosti pochv vozbuditelem gel'mintosporioznoi gnili zernovykh kul'tur [Drawing up and Application of Phytopathological Soil Maps forHelminthosporium on Cereal Crop]. Novosibirsk, 1987.

6. Isaichev V.V., Gorbachev I.V., Pritsenko V.V. e.a. Zashchita rastenii ot vreditelei /Pod redaktsiei V.V. Isaicheva [Protection of Plants against Pests. V.V. Isaichev (ed.)]. Moscow, 2002.

7. Sorokin O.D. Prikladnaya statistika na komp'yutere [Applied Statistics on Computer]. Krasnoobsk, 2004.

8. Toropova E.Yu. Ekologicheskie osnovy zashchity rastenii ot boleznei v Sibiri/Pod red. V.A. Chulkinoi [Basic Ecological Approaches to Plant Protection against

Diseases in Siberia. V.A. Chulkina (ed.)]. Novosibirsk, 2005.

9. Zakharov A.F., Toropova E.Yu. Sibirskii vestnik sel'skokhozyaistvennoi nauki, 2007, 8: 11-14.

10. Marmuleva E.Yu., Toropova E.Yu., Davydova N.V. Vestnik NGAU (Novosibirsk), 2009, 2(10): 18-21.

11. Zhuchenko A.A. Materialy Mezhdunarodnoi nauchno-prakticheskoi konferentsii «Biologicheskaya zashchita rastenii-osnova stabilizatsii agroekosistem» [Proc.

Int. Sci.-Pract. Conf. «Biological Crop Protection as a Basis of Sustainable Agroecosystems»]. Krasnodar, 2008: 5-32.

12. Kovalenkov V.G., Tyurina N.M. Materialy Mezhdunarodnoi nauchno-prakticheskoi konferentsii «Sovremennye sredstva, metody i tekhnologii zashchity rastenii» [Proc. Int. Sci.-Pract. Conf. «Modern Methods and Technologies of Crop Protection»]. Novosibirsk, 2008: 85-90.

13. Grebennikov V.S. Tainy mira nasekomykh [The Mysteries of the World of Insect]. Novosibirsk, 1990.

14. Tishler V. Sel'skokhozyaistvennaya ekologiya /Pod red. M.S. Gilyarova [Agricultural Ecology. M.S. Gilyarov (ed.)]. Moscow, 1971.

15. Kryukova E.A., Malanina Z.I., Kolmukidi S.V. Zashchita i karantin rastenii, 2011, 4: 20-23.

16. Chulkina V.A., Shamanskaya L.D., Toropova E.Yu. e.a. Fitosanitarnaya optimizatsiya agroekosistem plodovykh i yagodnykh kul'tur /Pod redaktsiei V.A. Chulkinoi, V.I. Usenko [Phytosanitary Optimization of Agroecosystems of Fruit and Berry Crops. V.A. Chulkina, V.I. Usenko (eds.)]. Moscow, 2006. 